\title{
THE EFFICIENCY OF PUBLIC EXPENDITURE AND ECONOMIC GROWTH IN THE COUNTRIES OF THE WESTERN BALKANS
}

\author{
Ljiljana Prole ${ }^{1}$, Dragana Petkoviće ${ }^{2}$ \\ ${ }^{1}$ State Audit Institution, Belgrade \\ 2 Tourist organization of the city of Niš, Niš
}

Corresponding: prole.ljiljana@gmail.com ${ }^{1}$

Review article

Received: 09.03.2021; Accepted: 19.05.2021

\begin{abstract}
The countries of the Western Balkans are facing a number of challenges. One of the most acute ones, certainly,is improving the efficiency of public expenditure. Having this in mind, the main research objective of the paper is to present the interdependence between public expenditure and economic growth in the Western Balkans. In addition, the analysis is focused on the efficiency of public expenditure in the group of the above-stated countries, as well as the relationship between the size of public expenditure and its efficiency in these countries. Data from the International Monetary Fund, the World Bank and the World Economic Forum were used for the analysis. The results reveal that this interdependence in the countries of the Western Balkans, in addition to different intensity, has a different direction.
\end{abstract}

Keywords: public expenditure, economic growth, efficiency, Western Balkans.

\section{Introduction}

Recent decades have seen the upurge of various examination of the relationship between the size of public expenditure and the rate of economic growth, due tothe fact that the growth of the public sector and the low rate of economic growth have become one of the key characteristics of modern economi- es. The key dilemma in the literature is whether public expenditure drives economic growth or whether economic growth is the factor that causes public expenditure.

According to Musgrave, [Musgrave et al., 1989] the presence of the state in the economic domain of modern market economies stems from three main functions that it 
Prole Lj. et al., The Efficiency of Public Expenditure and Economic Growth in the Countries of the Western Balkans

must fulfill: allocation, distribution and stabilization functions. The allocation function refers to the inefficiency or inability of the market to provide public goods, the distribution function refers to the management of income inequality and wealth within an economy, while the stabilization function focuses on managing economic flows in order to achieve macroeconomic stability (foreign trade balance, price stability, real GDP growth and full employment). In order to perform these functions, the state, among other things, collects revenues in various ways and spends those funds diversily. Eachaction of the state has its repercussions on the economy, whether positive or negative, and represents a significant challenge of modern public finances how to conduct fiscal policy with the aim of simultaneously achieving the stated tasks of the state.

\section{Literature review}

Numerous studies have been conducted on the interdependence of public expenditure and economic growth. More recently, research has shown that the link between government expenditure and economic growth has a positive outcome. Saez and the co-authors used for their research a regression analysis for examining the impact of the government size on the eco- nomic growth of EU countries. The analysis covers the period between 1994 and 2012. The results show the existence of positive relationship in Portugal and the United Kingdom, while Austria, Finland, Italy, Sweden, Belgium, France, Greece, Ireland, Luxembourg, the Netherlands and Spain are characterized by a negative relationship between public spending and economic growth. They also come to the conclusion that the intensity and direction of the impact of public expenditure on economic growth may vary depending on the size of the public sector.

Jin-young [Jin-young et al, 2015] used the pooled ordinary least square (OLS) method, fixed-effect models, and random effects models to study the magnitude and variability of public expenditure in South Korea, as well as their impact of economic growth. They found that there is a significant negative relation between public expenditure and economic growth. The research started from the assumption that public expenditure affects economic growth, however the conclusion was drawn that this impact is not statistically significant. In addition, the authors confirmed that variations in government expenditure play a significant role in increasing economic fluctuations. 
Folster \& Henrekson [2001] applied extreme limit analysis to determine and measure the interdependence between public expenditure and economic growth. The subject of their research were 23 high-income OECD countries in the period between 1970 and 1995. According to the results they obtained, when $\mathrm{pu}^{-}$ blic expenditure (including taxes) increases by $10 \%$ in high-income countries, economic growth falls by $0.7-0.8 \%$.

\section{The efficiency indicators of public expenditure}

The efficiency of public expenditure is also analyzed in relation to the goals, including the state as a whole as well as individual sectors, measures and policies. If, for example, the primary goal of the state is to reduce the risk of poverty, then efficiency is viewed on the basis of the ratio of expenditure for social transfers and relative poverty rates before and after transfers. [European Commission, 2016, 7] Measuring efficiency in the social sector, forexample, is a great challenge due to the fact that the results are very difficult to measure and considering that they are influenced by numerous other factors (economic development, employment, preferences and habits ...), and that the inputs (expressed, for example, as expenditure for individual social benefits) are often aimed at meeting several goals at the same time.

Attempts to measure the efficiency of public expenditures with composite indicators can be found in the literature. Afonso et al. [2010] define Public Sector Performance as indicators of the output of public activities. To that end, they put the obtained value in relation to the funds spent on that activity in order to obtain the efficiency of the public sector (Public Sector Efficiency). The calculation of public sector success is done using the following formula:

$$
U J S_{i}=\sum_{j} U J S_{i j}
$$

Where:

$U J S_{i}$ - Success indicator for public sector for i-thcountry

$U J S_{i j}$ - a sub-indicator of the success of the public sector for the $j$-th activity in the $i$-th country, where

$$
U J S_{i j}=f\left(I_{k}\right),
$$

Which means that the value of that sub-indicator depends on the value of a socio-economic indicator. Selected sub-indicators are divided into process and traditional subindicators. The following subindicators were chosen as process sub-indicators the quality of administration, health and education, while the traditional sub-indicators 
Prole Lj. et al., The Efficiency of Public Expenditure and Economic Growth in the Countries of the Western Balkans

showed the quality of the three basic functions of the public sector. Moreover, each of these subindicators would consist of different socio-economic indicators. For example, for the administration, indicators for corruption, quality of the judiciary, participation of the gray economy, etc. are included. In relation to consumption for these categories, public sector efficiency indicators are obtained, which are used for comparison between countries. However, such a comparison, as they themselves pointed out, has many shortcomings. One of them is related to the aspect of connecting the invested resources with clearly defined outputs and highlighting the impact of public expenditure on these outputs. Another disadvantage is the choice of sub-indicators, which can be highly subjective and may contain prejudices of the one who makes their choice. For example, the "Public Sector Size" indicator may contain assumptions about public sector tasks. [Mandl et al., 2008] Notwithstanding the above, composite indicators represent a very important tool for monitoring various phenomena by institutions such as the World Bank and the Organization for Economic Cooperation and Development. [Nardo et al., 2005]

The World Bank also uses 6 indicators to measure the quality of governance, one of which is the effectiveness of government (Worldwide Governance Indicators). This indicator combines perceptions about the quality of public services, the quality of public service offices and the degree of their independence from political pressures, the quality of policy formulation and implementation, as well as the government's commitment to implementing these policies. The value of the indicator is expressed in units of standard normal distribution, ie. in the range of about -2.5 to 2.5 , and based on the percentile rank, it can be seen in which part of the distribution, the country is in relation to other countries in the world.

The World Economic Forum's Global Competitiveness Report also provides perceptions of government efficiency or public sector performance. According to the methodology of the World Economic Forum, managers in the highest positions in this segment assess the extent to which state funds are wasted and wasted unnecessarily. Assigning grades from 1 to 7 , they also assess regulatory burdens, the effectiveness of the legislative framework in resolving disputes and the ability to challenge regulations, as well as government transparency in formulating various policies. 
The characteristics of the Western Balkan countries

According to the World Bank methodology, the countries of the Western Balkans belong to the group of middle-developed countries with a higher middle level of income. The level of development of the countries of the Western Balkans is low in relation to European standards. [Matković, 2017] The following table provides an overview of GDP per capita in the Western Balkans in the period from 2010 to 2019.

Table 1. BDP per capita ( $p p p$ in $\$$ ) in the countries of the Western Balkan in the period 2010-2019

\begin{tabular}{|l|r|r|r|r|c||}
\hline Year & Albania & $\begin{array}{c}\text { Bosnia and } \\
\text { Herzegovina }\end{array}$ & Montenegro & $\begin{array}{c}\text { North } \\
\text { Macedonia }\end{array}$ & Serbia \\
\hline \hline 2010 & $9,724.48$ & $9,564.51$ & $13,751.80$ & $11,195.74$ & $13,093.11$ \\
\hline 2011 & $10,207.74$ & $9,971.44$ & $14,471.96$ & $11,682.80$ & $13,742.30$ \\
\hline 2012 & $10,526.27$ & $10,292.31$ & $13,863.94$ & $11,908.50$ & $13,929.19$ \\
\hline 2013 & $10,570.98$ & $11,003.76$ & $14,870.35$ & $12,716.66$ & $14,624.10$ \\
\hline 2014 & $11,259.26$ & $11,410.81$ & $15,371.39$ & $13,423.77$ & $14,657.08$ \\
\hline 2015 & $11,662.00$ & $12,013.85$ & $16,336.11$ & $13,884.95$ & $14,922.10$ \\
\hline 2016 & $12,077.60$ & $13,069.49$ & $18,197.60$ & $15,127.59$ & $15,832.20$ \\
\hline 2017 & $13,088.31$ & $13,836.66$ & $19,703.46$ & $15,640.30$ & $16,599.41$ \\
\hline 2018 & $13,982.67$ & $14,828.09$ & $21,207.89$ & $16,438.79$ & $17,841.76$ \\
\hline 2019 & $14,534.11$ & $15,603.62$ & $22,347.92$ & $17,313.01$ & $18,971.85$ \\
\hline \hline
\end{tabular}

Source: International Monetary Fond, World Economic Outlook 2020

According to the data shown in Table 1, the lowest living GDP in the first year of observation was in Albania, while the highest level was recorded by Montenegro. The same situation is in the last year of observation. The largest relative increase in GDP per capita in 2019 in comparison to 2010 was achieved by Bosnia and Herzegovina (63.14\%), followed by Montenegro with an increase of $62.51 \%$, then North Macedonia with $54.64 \%$, Albania with $49.46 \%$ and finally the
Republic of Serbia with an increase of $44.90 \%$.

In the Western Balkans, poverty and the risk of poverty are high in comparison toEuropean standards. Absolute consumption poverty is still present in all Western Balkan countries. The extremely unfavorable characteristics of the labor market in the Western Balkans represent one of the greatest challenges for both development and social policy. Employment and ac- 
Prole Lj. et al., The Efficiency of Public Expenditure and Economic Growth in the Countries of the Western Balkans

tivity rates are low, and unemployment rates are high in all countries and are much more unfavorable than in EU countries. At the same time, the youth unemployment rate is about twice as high as the general unemployment rate.

The level of employment in itself is not an appropriate indicator, because the quality of employment is a very important factor, especially when the gray economy in the Western Balkans is taken into account. Labor force surveys show that every fifth employee in Serbia, Macedonia and Montenegro works in the informal economy. More precisely, in Serbia, it is $20.4 \%$, in Macedonia $19.2 \%$, while in Montenegro it is $22.3 \%$. In Albania, the percentage is even higher and it amounts to 34.1. This part of the employees is recruited mostly from the poor, [World Bank, 2016, 33-35] moreover, they do not have the right to social security and social protection, often earn less and do not contribute to the total revenues of the budget and social funds from which different rights are financed.

The unfavorable situation on the labor market is additionally burdened by the gap between education and jobs offered, the obsoles- cence of knowledge and skills of the long-term unemployed. On the other hand, the reluctance of employers to invest in employee training is also characteristic. [Arandarenko \& Bartlett, 2012] According to research conducted by the International Monetary Fund, the main causes of the extremely unfavorable situation on the labor market are no longer primarily institutional reasons, rigid labor market institutions (excessive protection of workers during dismissal, high severance pay and unemployment benefits, etc.), nor in high labor costs (although this question is also raised for certain market segments in Serbia, $\mathrm{BiH}$ and Macedonia). The main problems are structural in nature and are related to macroeconomic stability and improving the investment climate. [Kovtun et al., 2014]

According to the World Bank, the public sector in the Western Balka$\mathrm{ns}$ is too inefficient and provides public services that are too expensive. [World Bank, 2015] The movement of public expenditures expressed as a percentage of GDP of these countries is shown in the following table. 
Table 2. Flow of public expenditure (in\% of GDP) in the countries of the Western Balkans

in the period 2010-2019

\begin{tabular}{||c|r|r|r|r|r||}
\hline Godina & Albania & $\begin{array}{c}\text { Bosnia and } \\
\text { Herzegovina }\end{array}$ & Montenegro & $\begin{array}{c}\text { North } \\
\text { Macedonia }\end{array}$ & Serbia \\
\hline \hline 2010 & 29.39 & 49.50 & 46.65 & 32.51 & 42.86 \\
\hline 2011 & 28.92 & 46.42 & 45.28 & 31.86 & 41.64 \\
\hline 2012 & 28.23 & 46.93 & 45.71 & 33.26 & 45.13 \\
\hline 2013 & 29.19 & 45.05 & 45.83 & 31.67 & 42.31 \\
\hline 2014 & 31.73 & 46.27 & 44.21 & 31.71 & 44.81 \\
\hline 2015 & 30.38 & 43.44 & 46.38 & 32.22 & 42.69 \\
\hline 2016 & 29.14 & 42.20 & 47.52 & 31.11 & 41.88 \\
\hline 2017 & 29.15 & 40.76 & 47.19 & 31.76 & 40.14 \\
\hline 2018 & 28.82 & 41.27 & 47.19 & 30.40 & 40.72 \\
\hline 2019 & 29.38 & 41.11 & 44.98 & 31.19 & 42.12 \\
\hline \hline
\end{tabular}

Source: International Monetary Fund, World Economic Outlook 2020

It can be noticed that, according to the percentage of GDP covered by public expenditure, the countries of the Western Balkans can be classified into two groups. In the first group of countries, public expenditure amount to about $30 \%$ of GDP, including Albania and North Macedonia. In the second group of countries, the amount of public expenditures is over $40 \%$ of GDP, and this includes Bosnia and Herzegovina, Montenegro and Serbia.

\section{Data and analysis}

The information basis for the analysis conducted in this paper consists of data obtained from the
International Monetary Fund, the World Bank and the World Economic Forum. The initial assumption in the paper is that the countries of the Western Balkans reveal an interdependence between public expenditure and economic growth. In order to prove this hypothesis, a correlation analysis was conducted, ie. calculated nonparametric indicator of the correlation between the share of public expenditure in GDP and the GDP growth rate in the countries of the Western Balkans. GDP growth rates in the Western Balkans are calculated according to the data given in Table 1. 
Prole Lj. et al., The Efficiency of Public Expenditure and Economic Growth in the Countries of the Western Balkans

Table 3. GDP growth rates in the Western Balkansin the period 2011-2019

\begin{tabular}{||r|r|r|r|r|r|}
\hline Year & Albania & $\begin{array}{c}\text { Bosnia and } \\
\text { Herzegovina }\end{array}$ & Montenegro & $\begin{array}{c}\text { Nort } \\
\text { Macedonia }\end{array}$ & \multicolumn{1}{c|}{ Serbia } \\
\hline \hline 2011 & 4.97 & 4.25 & 5.24 & 4.35 & 4.96 \\
\hline 2012 & 3.12 & 3.22 & -4.20 & 1.93 & 1.36 \\
\hline 2013 & 0.42 & 6.91 & 7.26 & 6.79 & 4.99 \\
\hline 2014 & 6.51 & 3.70 & 3.37 & 5.56 & 0.23 \\
\hline 2015 & 3.58 & 5.28 & 6.28 & 3.44 & 1.81 \\
\hline 2016 & 3.56 & 8.79 & 11.39 & 8.95 & 6.10 \\
\hline 2017 & 8.37 & 5.87 & 8.28 & 3.39 & 4.85 \\
\hline 2018 & 6.83 & 7.17 & 7.64 & 5.11 & 7.48 \\
\hline 2019 & 3.94 & 5.23 & 5.38 & 5.32 & 6.33 \\
\hline
\end{tabular}

Source: Calculated according to Table 1

According to the obtained results, capita was recorded $(-4.20 \%$ in Montenegro shows the largest oscil- 2012), and at the same time, the lations in GDP per capita in the largest relative increase in GDP analyzed period. Only in Monte- per capita was achieved in Montenegro, a relative decline in GDP per negro (11.39\% in 2016).

Table 4. Interdependence of public expenditure GDP growth rate per capita in the countries of the Western Balkans

\begin{tabular}{|l|c|}
\hline \multicolumn{1}{|c|}{ Country } & $\begin{array}{c}\text { Spearman's rank correlation } \\
\text { coefficient }\end{array}$ \\
\hline \hline Albania & $0,067(0,865)$ \\
\hline Bosnia and Herzegovina & $-0,617(0,077)$ \\
\hline Montenegro & $0,862(0,003)$ \\
\hline North Macedonia & $-0,783(0,025)$ \\
\hline Serbia & $-0,618(0,077)$ \\
\hline \hline
\end{tabular}

Note: Achieved levels of significance are given in parentheses

Source: Author's calculations

The calculated values of Spearman's correlation coefficient point to different conclusions about the relationship between public expenditure and economic growth in the Western Balkans. Namely, in Alba- nia and Montenegro, there is a positive relationship between the flow of public expenditure and the rate of economic growth. For Montenegro, this connection is very strong and statically significant, 
while, when it comes to Albania, the connection between public expenditure and the rate of economic growth is negligible. In Bosnia and Herzegovina, North Macedonia and Serbia, the link between public expenditure and economic growth is negative. As for the intensity of interdependence, it is the strongest in North Macedonia (-0.783).

According to the methodology of the World Economic Forum, the first pillar within the Global Competitiveness Index represent the institutions. Until the change of this methodology, performed in 2018, the institution pillar as an integral component contained the indicator of Public Sector Performance, within which one of the indicators was the Efficiency of Public Expenditure. Precisely due to the change in the methodology for analyzing the public sector in the Western Balkans, the data from the Global Competitiveness Report up to 2017 will be used. The values of the indicator the efficiency of public spending for the countries of the Western Balkans, as well as their ranking according to this indicator are given in the table below.

Table 5. Rank and score of indicator efficiency of public expenditure in the countries of the Western Balkans

\begin{tabular}{|c|c|c|c|c|c|c|c|c|}
\hline Country & Indicator & ت্ & : & $\stackrel{\infty}{\stackrel{2}{\sim}}$ & 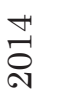 & $\stackrel{20}{\stackrel{2}{\circ}}$ & $\begin{array}{l}0 \\
\stackrel{1}{0} \\
\stackrel{N}{N}\end{array}$ & 突 \\
\hline \multirow{2}{*}{ Albania } & Rank & 51 & 66 & 77 & 63 & 64 & 64 & 38 \\
\hline & Score & 3.5 & 3.3 & 3.1 & 3.3 & 3.3 & 3.3 & 3.9 \\
\hline \multirow{2}{*}{$\begin{array}{l}\text { Bosnia and } \\
\text { Herzegovina }\end{array}$} & Rank & 124 & 139 & 146 & - & 137 & 133 & 112 \\
\hline & Score & 2.3 & 2 & 1.7 & - & 1.7 & 1.7 & 2.4 \\
\hline \multirow{2}{*}{ Montenegro } & Rank & 23 & 30 & 46 & 55 & 57 & 56 & 52 \\
\hline & Score & 4.2 & 3.9 & 3.6 & 3.4 & 3.4 & 3.4 & 3.6 \\
\hline \multirow{2}{*}{$\begin{array}{l}\text { Nort } \\
\text { Macedonia }\end{array}$} & Rank & 74 & 61 & 43 & 30 & 31 & 31 & \\
\hline & Score & 3.1 & 3.4 & 3.6 & 3.8 & 3.8 & 3.8 & \\
\hline \multirow{2}{*}{ Serbia } & Rank & 130 & 132 & 130 & 132 & 129 & 124 & 44 \\
\hline & Score & 2.2 & 2.2 & 2.3 & 2.2 & 2.2 & 2.2 & 3.7 \\
\hline
\end{tabular}

Source: World Economic Forum, The Global Competitiveness Report 2011., ..., 2017-18.

Data from Table 5 show that perceptions of public sector efficiency (Public Expenditure Efficiency) in the Western Balkans are more unfavorable than in most more developed EU countries. Judging by this indicator, Montenegro and North Macedonia are in the first 
Prole Lj. et al., The Efficiency of Public Expenditure and Economic Growth in the Countries of the Western Balkans

half of the countries covered by the analysis, Albania is around the middle of the list, while Serbia and Bosnia and Herzegovina are at the bottom of the list. These two coun- tries, and especially Serbia, have seen an increase in the value of the Public Expenditure Efficiency indicator in the last year covered by the analysis.

Table 6. Interdependence of the size of public expenditure and its efficiency

\begin{tabular}{|l|c|}
\hline \multicolumn{1}{|c|}{ Country } & Spearman's rank correlation coefficient \\
\hline \hline Albania & $-0,296(0,520)$ \\
\hline Bosnia and Herzegovina & $0,039(0,933)$ \\
\hline Montenegro & $-0,337(0,466)$ \\
\hline North Macedonia & $-0,394(0,382)$ \\
\hline Serbia & $-0,535(0,296)$ \\
\hline
\end{tabular}

Source: Author's calculations

As in the case of examining the interdependence of public expenditure and value growth, a correlation analysis was applied to examine the interdependence of the size of public expenditure and its efficiency in the countries of the Western Balkans. More precisely, an adequate indicator of interdependence was calculated for this number of data - Spearman's rank correlation coefficient. The results show that there is a negative alignment between the volume of public expenditure and its efficiency in most countries of the Western Balkans, except in Bosnia and Herzegovina, where this agreement is positive but negligible (0.039). Bearing in mind that none of the values of the correlation coefficient is statistically significant, which is logical, due to the short time period covered by the analysis, it is appropriate to limit the interpretation only to the observed period. Negative interdependence implies the fact that, in the analyzed period, the increase in public expenditure in the Western Balkans was accompanied by a decrease in efficiency and vice versa.

\section{Conclusion}

While, on the one side, there are conditions of numerous needs and pressures that lead to increase in expenditure, and on the other, there is almost no room for a significant increase in taxes, improving the efficiency of public expenditure is a necessary part of responding to the challenges facing the Western Balkans. Measuring the efficiency and effectiveness of the public sector and government, according to the methodology of the World Bank 
and the World Economic Forum, is largely based on perceptions, which, although not representing objective indicators, can serve as a good approximation of the situation.

Increasing the efficiency of public spending in the Western Balkans is not an alternative, but the most important complementary strategy, independent of other possible options. In addition, the increase of public expenditure is a precondition for the implementation of the strategic commitments of the Western Balkan countries, because it enables the creation of budget space for a differently directed state policy. Increasing the efficiency of public expenditure does not only mean saving funds that are "unnecessarily" spent, but also improving the outcomes and quality of services for citizens with the given funds. Improving efficiency can also mean changing the structure of expenditures within the state as a whole (reducing spending on social transfers and increasing it on education) or within each individual sector.

\section{References}

Afonso, A., Schuknecht, L. \& Tanzi, V. (2010). Public sector efficiency: evidence for new EU member states and emerging markets. Applied Economics,42(17), 21472164.
Arandarenko, M. \& Bartlett, W. (2012). Labour Market and Skills in the Western Balkans. Belgrade: FREN -Foundation for the Advancement of Economics.

European Commission. (2016). European Semester Thematic Fiche: Poverty and Social Exclusion.

Folster, S. \& Henrekson, M. (2001). Growth effects of government expenditure and taxation in rich countries. Eur. Econ. Rev. 45, 1501-1520.

Jin-young, H., Ho, L.S. (2015). The Effectiveness of Government Expenditure on Economic Growth and Volatility. Korean Assoc. Public Policy 2015, 33, 85-105.

Kovtun, D., Meyer Cirkel, A., Murgasova, Z., Smith, D. \& Tambunlertchai, S. (2014). Boosting Job Growth in theWestern Balkans. IMF.

Mandl, U., Dierx, A. \& Ilzkovitz, F. (2008). The effectiveness and efficiency of public spending (No. 301). Directorate General Economic and Monetary Affairs (DG ECFIN), European Commission.

Matković, G. (2017). Država blagostanja u zemljama Zapadnog Balkana - izazovi i opcije, Beograd, Centar za socijalnu politiku. 
Prole Lj. et al., The Efficiency of Public Expenditure and Economic Growth in the Countries of the Western Balkans

Međunarodni monetarni fond, Sáez, M.P., Álvarez-García, S. \& World Economic Outlook 2020. Rodríguez, D.C. (2017). Governhttps://www.imf.org/en/publicatio ment expenditure and economic ns/weo.

Musgrave, R. \& Musgrave, P., (1989). Public finance in theory and practice (5th ed.). New York McGraw-Hill Book Co.

Nardo, M., Saisana, M., Saltelli, A., Tarantola, S., Hoffman, A. \& Giovannini, E. (2005). Handbook growth in theEuropean Union countries: New evidence. Bull. Geogr. -Socio-Econ. Ser. 36, 127133.

Svetski ekonomski forum, The Global Competitiveness Report 2011., ..., 2017-18.

https://www.weforum.org/reports on constructing composite indicators.

\footnotetext{
${ }^{1}$ https://orcid.org/0000-0001-6491-0327

2 https://orcid.org/0000-0003-4283-5180
} 


\title{
EFIKASNOST JAVNIH RASHODA I PRIVREDNI RAST U ZEMLJAMA ZAPADNOG BALKANA
}

\author{
Ljiljana Prole ${ }^{1}$, Dragana Petkovićc ${ }^{2}$ \\ ${ }^{1}$ Državna revizorska institucija, Beograd \\ ${ }^{2}$ Turistička organizacija grada Niša, Niš
}

Korespondencija:prole.ljiljana@gmail.com ${ }^{1}$

Rezime: Zemlje Zapadnog Balkana se suočavaju sa brojnim izazovima. Jedan od njih je, svakako, unapređenje efikasnosti javnih rashoda. S tim u vezi, predmet istraživanja u ovom radu je međzavisnost između javnih rashoda i privrednog rasta u zemljama Zapadnog Balkana. Pored toga, analiza je usmerena i na efikasnost javnih rashoda u ovoj grupi zemalja, kao i vezu između obima javnih rashoda i njihove efikasnosti u ovim zemljama. Za analizu su korišćeni podaci Međunarodnog monetarnog fonda, Svetske banke i Svetskog ekonomskog foruma. Rezultati su pokazali da u zemljama Zapadnog Balkana ta međuzavisnost, pored različitog intenziteta, ima različit smer.

Ključne reči: javna potrošnja, ekonomski rast, efikasnost, Zapadni Balkan. 
